\title{
John Hardy
}

In science, as in fashion, it pays to have a healthy irreverence for the trends. John Hardy has helped outfit clashing views about the origins of Alzheimer disease, but has always managed to steer clear of cliché.

Everyone who knows John Hardy has a favorite John Hardy story. In one illustrative tale, the noted neurobiologist was traveling with his colleague Gerard Schellenberg. Hardy unwittingly picked up the wrong suitcase when they parted for the evening, and emerged the next morning obliviously decked out in Schellenberg's clothes.

"He said he just thought his wife had bought him some new clothes," recalls Karen Duff, Hardy's former postdoctoral fellow at the University of South Florida in Tampa. "He's in his own little world," Duff says. "It's very endearing, but it can also get frustrating."

Affectionately nicknamed 'Scruffy' by former lab members, Hardy has an idiosyncratic - some would say challenged-dress sense that has become the stuff of legend. At last year's meeting of the Society for Neuroscience, an informal gathering of researchers unanimously christened him the worst-dressed scientist in the field. During an interview at his laboratory, he wore chinos and leather flip-flops over dingy cotton tube socks, and in the course of the day his big toe began to peek through a hole in one sock. When he worked at the Mayo Clinic in Jacksonville, Duff says, Hardy was directed to keep his distance from areas in which he might be seen by patients.

Alison Goate, another former postdoc and a collaborator, remembers Hardy careering around London on an old motorbike, usually wearing tattered canvas deck shoes. She giggles when describing the mayhem of his office, but says, "Obviously, his mind is much more organized."

Indeed, Hardy is a prolific and pioneering researcher in the study of neurodegenerative diseases. His 30-member lab at the US National Institute on Aging (NIA) generates about one paper per week, focusing their efforts on finding disease-associated genes, and on the origins of Alzheimer and Parkinson diseases.

In the contentious world of Alzheimer research, Hardy is a 'BAPtist': he believes that deposition of $\beta$-amyloid is the triggering event in Alzheimer disease. In 1991 he and Goate won the race to identify a mutation in the gene encoding $\beta$-amyloid precursor protein in families with early-onset Alzheimer disease.

"I remember when we found the mutation, going back and telling my then-wife that this was going to change our life," says Hardy during an interview at a coffeehouse in New York's Greenwich Village. "I felt we'd cracked Alzheimer's. I felt we'd done something that had made a real difference." As he talks, Hardy sips his third iced latte and alternately scrolls through PowerPoint illustrations on his laptop, checks his BlackBerry for emails and doodles pictures of neurons in a notebook.

But Hardy can also claim allegiance to the opposing group, called 'Tauists.' His groundbreaking Nature paper links mutations in the gene that encodes tau to the neurofibrillary tangles of frontotemporal dementia (Nature 393, 702-705; 1998). Hardy counts the discovery among the two or three biggest moments of his career, and remembers an intense rush when they comprehended the pattern of effect: "You go from no understanding to total understanding in a 10-minute conversation."

Hardy has always been good at developing protégées and infecting them with his enthusiasm, says Mike Hutton, one of Hardy's key collaborators in Florida. As Hardy's postdoc, Hutton received primary authorship for the Nature paper.

Hardy's decision three years ago to join the NIA surprised some who had worked with him. "John and bureaucracy do not get along — he really doesn't like rules and establishment, so he blazes his own path," says Duff, now an associate professor at the Nathan Kline Institute in New York.

Hardy admits that he is "temperamental" and generally ill-suited to government, but says change keeps him on his toes. "There's a tendency just to slip into the same routine, you know? You don't want to get too comfortable - at least I don't." He has consistently uprooted himself every five to seven years, and says he expects to do so at least once more.

In Bethesda, Hardy's staff lay claim to the master office suite, while he occupies a far-flung cell that looks like it could double as a broom closet. "This is a good way to defend against others complaining," he says.

But one gets the impression that Hardy feels more comfortable operating at a degree of remove. He commands little attention as he kicks up dust in the corridors, and his staffers flash polite but nonchalant smiles as they peek up or pass in the hallway.

"He cruises along on the tops of all the waves, fairly oblivious to the chaos he's caused around him," Duff says half-jokingly. In the past, Hardy has given assistants his signature authority and preferred not to be bogged down by details. "He instills a sense of keeping sight of the big picture, not taking short-term setbacks to heart," Duff says. "It does give you a sense that anything's possible."

"There's a tendency just to
slip into the same routine,
you know? You don't want
to get too comfortable_-at
least I don't."

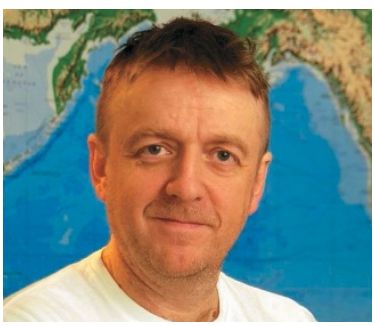

In Hardy's world, anything is indeed possible. He harbors notions of writing about the world's street foods and once managed to ring up a $\$ 1,100$ tab while drinking whiskey and singing 'Yellow Submarine' in a karaoke bar in Osaka.

Legend holds that in the late 1980s, visitors to Hardy's laboratory in London were greeted with a poem taped to his office door: "Amyloid is not the gene/ The scientists have come clean/ They said it was duplicated/ But that could not be replicated/ Amyloid is not the gene."

Hardy composed the verse and, the story goes, had it rejected for publication by Science. The poem was later preserved at the behest of his lab, illustrating his lighthearted humor and, indirectly, his capacity to test out his assumptions.

"Most of the time he's doing real science, which is not trying to prove your own hypothesis, but to disprove it," says Mark Smith, a prominent opponent of the amyloid orthodoxy and a researcher at Case Western Reserve University in Cleveland. "I believe [Hardy] would turn around and modify his hypothesis in the face of any compelling evidence against it [where] many of his followers would still cling to it."

Still, Hardy is frequently obliged to attend meetings and defend the amyloid hypothesis against the barbs of those who dispute it. It's a duty that, frankly, he says he could do without.

"I'm kind of tired of doing the same debate over and over and over again," he says. "It's like being asked to sing 'A Whiter Shade of Pale' every time I go out. I don't feel like singing that song anymore. I have other albums I want to sell."

Bruce Diamond, Bethesda 